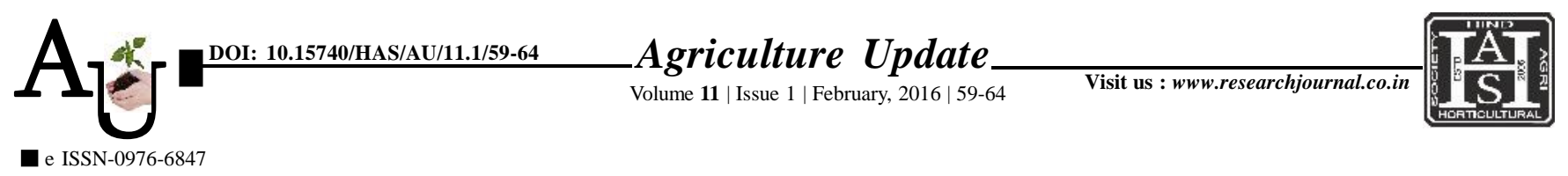

\title{
Research Article: Boosting summer moong productivity through front line demonstrations
}

口 GURMEET SINGH DHILLON

Article Chronicle: Received :

01.01.2016;

Revised :

08.01.2016;

Accepted :

21.01.2016

KEY Words:

Summer moong, Front line demonstrations, Extension gaps, Technology gaps, Technology index

Author for correspondence :

\section{GURMEET SINGH}

DHILLON

Krishi Vigyan Kendra (P.A.U.), BATHINDA (PUNJAB) INDIA

Email: kvkdhillon@ gmail.com
SUMMARY : The present study was conducted by Krishi Vigyan Kendra Bathinda in operational village Killi Nihal Singh under the project "National Initiatives on Climate Resilient Agriculture" (NICRA).The village was adopted under this project and operational area was village Killi Nihal Singh. Krishi Vigyan Kendra Bathinda has conducted total 58 front line demonstrations on summer moong in 20 hectares area during the Rabi season from year 2011 to 2015. The productivity and economic returns of summer moong in demonstrated plots were calculated and compared with the corresponding farmers' practices (local check). The data obtained were pooled for five years. The results of the study revealed that the average yield of summer moong under FLD plots varied between $10.80 \mathrm{q} /$ ha to $11.20 \mathrm{q} / \mathrm{ha}$, whereas, under the farmers' practice, it varied between $8.90 \mathrm{q} /$ ha to $10.00 \mathrm{q} / \mathrm{ha}$. The FLD plots recorded a per cent increase in yield to the tune of 8.70 to 21.30 . It was observed that on an average 13.4 per cent higher grain yield was recorded in demonstration plots than farmers' practices. The extension gap and technology gap were recorded $1.08 \mathrm{q} / \mathrm{ha}, 0.27 \mathrm{q} / \mathrm{ha}$, respectively and technology index was measured 2.39 per cent, The additional investment of Rs.1,313/ha coupled with scientific monitoring of demonstrations and non-monitoring factors resulted in additional return of Rs. 5,617/ha over the farmer practice. The increment in yield of summer moong crop under front line demonstrations was due to dissemination of improved and latest technologies, HYV, recommended seed rate, fertilization and plant protection measures. Fluctuating minimum selling price of summer moong different years influenced the economic returns per unit area.

How to cite this article : Dhillon, Gurmeet Singh (2016). Boosting summer moong productivity through front line demonstrations. Agric. Update, 11(1): 59-64. 